\title{
Reactions of the Phenylium Cation with Small Oxygen- and Nitrogen-Containing Molecules
}

\author{
Yasmin A. Ranasinghe* and Gary L. Glish \\ Department of Chemistry, University of North Carolina, Chapel Hill, North Carolina, USA
}

\begin{abstract}
The reactions of phenylium with water and ammonia and their methyl homologs have been investigated using a quadrupole ion trap and semiempirical molecular orbital calculations. The results indicate that both types of molecules react with phenylium through lone pair electrons even though, for methyl-containing compounds, insertion into a $\mathrm{C}-\mathrm{H}$ bond would lead to more stable products. For the excited adducts formed by reaction with methyl-containing reactant neutrals, the only dissociation observed is loss of a methyl radical. Neutral losses of $\mathrm{H}_{2}$ or $\mathrm{CH}_{4}$, which are more thermodynamically stable, are not observed, which indicates that these reactions are either not kinetically competitive or have high energy transition states due to the fact that the reactions would need to occur via orbital symmetry forbidden 1,2 eliminations. (J Am Soc Mass Spectrom 1996, 7, 473-481)
\end{abstract}

$\mathrm{T}$ he phenylium ion $\left(\mathrm{C}_{6} \mathrm{H}_{5}^{+}\right)$shows both carbonium- and carbene-type reactivity and attacks both $\sigma$ - and $\pi$-electron systems [1]. The electrophilicity of the phenylium ion, due to the vacant $s p^{2}$ orbital, results in strong ion-induced dipole interactions with neutral molecules. Previous studies of the reactions of phenylium with hydrocarbons and halohydrocarbons have been performed [1, 2]. Although these studies agree on the general reactivity of the phenylium ion, differences in the product ion structures were reported. These differences may be accounted for based on different experimental approaches and, in particular, different pressure regimes in which the experiments were performed. Studies of the reactivity of phenylium toward methanol also have been performed $[3,4]$. Differences in product ion distribution between these studies may again be attributable to the different pressure ranges in which the experiments were performed.

From a fundamental point of view, understanding the reactions of phenylium increases our understanding of the chemistry of isolated gas-phase ions. Additionally, the reactions of the phenylium ion are of an analytical concern because many aromatic species produce phenylium ions upon electron or chemical ionization. The reactivity of phenylium is of increased importance with the emergence of ion trapping mass spectrometric techniques. Mass spectra typically are obtained in tens of milliseconds with ion trapping instruments, which is several orders of magnitude longer than standard residence times of ions formed in

Address reprint requests and correspondence to Gary L. Glish, Department of Chemistry, University of North Carolina, CB 3290, Chapel Hill, NC: $27599-3290$.

* Current address: Becton Dickinson and Co., P.O. Box 120, 21 Davis Dr., Research Triangle Park, NC 27709-2016. ion sources for sector and linear quadrupole mass spectrometers. This increase in time raises the likelihood of the occurrence of unwanted ion-molecule reactions, especially when chemical ionization is performed with the corresponding relatively high number density of neutral molecules [5].

In this study we have used a quadrupole ion trap to investigate the reactions of phenylium with $R_{1} R_{2} O$ and $R_{1} R_{2} R_{3} N$, where $R_{1}, R_{2}, R_{3}=H, C H_{3}$. The operating characteristics of the quadrupole ion trap complement those of previous instruments, such as ion cyclotron resonance (ICR) spectrometers [1] and multiple quadrupoles [4] that have been used to study certain aspects of the reaction chemistry of phenylium. In particular, the neutral molecule number density in the quadrupole ion trap for chemical ionization is several orders of magnitude greater than that in ICR instruments, but several orders of magnitude lower than that used as reactant gases in multiple quadrupole systems. For multiple quadrupole systems in which the reaction occurs after mass selection, the reactant gas pressure is still several orders of magnitude greater than the reactant gas pressure in a quadrupole ion trap, but the overall pressures in the reaction regions are similar. This is due to the He buffer gas used in quadrupole ion traps [6], which allows increased probability of collisional stabilization compared to ICR. This collisional stabilization may be responsible for the formation of different product ions when phenylium reacts with methane [2].

\section{Experimental}

The theory, instrumentation, and methodology of quadrupole ion trap mass spectrometry have been discussed in detail elsewhere [7-9]. All experiments 
were performed with a Finnigan-MAT (San Jose, CA) ion trap mass spectrometer mounted in a custom vacuum system. All samples were used as supplied except for multiple freeze pump thaw cycles to remove any noncondensable gases. All chemicals except chlorobenzene were introduced into the vacuum system through a Varian leak valve. A constant uncorrected pressure of $1-5 \times 10^{-6}$ torr, determined with a Bayard-Alpert ionization gauge, was used. Chlorobenzene was pulsed into the cell via a General Valve Corporation Series 9 pulsed solenoid valve. The pulsed valve was opened for $300 \mu \mathrm{s}$; the chlorobenzene pressure peaked approximately $50 \mathrm{~ms}$ after triggering the pulsed valve. The scan function was such that the pulsed valve was triggered prior to the ionization pulse and the chlorobenzene pressure peaked during an electron ionization pulse of approximately $1 \mathrm{~ms}$. An rf (radiofrequency) ramp was used to isolate the $\mathrm{C}_{6} \mathrm{H}_{5}^{+}$ $(m / z 77)$ ion, which then reacted with the neutrals leaked in through the leak valves. Helium, which was used as the buffer gas at an uncorrected pressure of $2 \times 10^{-4}$ torr, also acted as the collision gas in tandem mass spectrometry (MS/MS) experiments. Resonant excitation with a 5- $\mathrm{V}_{\mathrm{p}-\mathrm{p}}$ 530-kHz signal was applied to the endcaps to resonantly eject the ions. Typically 10 scans were averaged in a spectrum and 10 spectra were averaged to obtain the data presented.

Collision-induced dissociation (CID) was performed by kinetic excitation of the parent ions with a resonant excitation voltage of a few hundred millivolts applied to the endcap electrodes. Optimum conditions were determined by adjustments of the voltage and the frequency to obtain the maximum total conversion of parent ions to product ions during a 20-ms excitation period.

Semiempirical molecular orbital calculations via the MOPAC package, version 6.0, were used in conjunction with the molecular modeling software program PCMODEL (Serena Software, Bloomington, IN) to estimate the heat of formation for ions that do not have known literature values. PCMODEL was used first to generate a structure based on molecular mechanics. This structure was then used as the starting structure for MOPAC, in which the AM1 (Austin Model 1) Hamiltonian was used [10]. In addition to ions with no experimental heats of formation, calculations were done for similar ions with known heats of formation to compare the accuracy of the calculations. The literature values [11] for the heats of formation of $\mathrm{C}_{6} \mathrm{H}_{5} \mathrm{OH}_{2}^{+}$ and $\mathrm{C}_{6} \mathrm{H}_{5} \mathrm{OH}\left(\mathrm{CH}_{3}\right)^{+}$were $14 \%$ lower than the semiempirically calculated value. By using this value as a correction factor, the heats of formation of similar even electron species $\mathrm{C}_{6} \mathrm{H}_{5} \mathrm{O}\left(\mathrm{CH}_{3}\right)_{2}^{+}$, $\mathrm{C}_{6} \mathrm{H}_{5} \mathrm{OH}\left(\mathrm{C}_{2} \mathrm{H}_{5}\right)^{\prime}, \mathrm{C}_{6} \mathrm{H}_{5} \mathrm{O}\left(\mathrm{C}_{2} \mathrm{H}_{5}\right)_{2}$, and $\mathrm{C}_{6} \mathrm{H}_{5} \mathrm{OCH}_{2}^{+}$ are reported as $14 \%$ lower than the semiempirically calculaled value. Similarly, the literature values for $\mathrm{C}_{6} \mathrm{H}_{5} \mathrm{NH}_{2}\left(\mathrm{CH}_{3}\right)^{+}$and $\mathrm{C}_{6} \mathrm{H}_{5} \mathrm{NH}\left(\mathrm{CH}_{3}\right)_{2}^{+}$were found to be lower by $8 \%$ than the calculated numbers and therefore the reported value for $\mathrm{C}_{6} \mathrm{H}_{5} \mathrm{~N}\left(\mathrm{CH}_{3}\right)_{3}^{+}$was adjusted by this value. MOPAC was used to calculate a relative potential energy surface for reactions by doing a series of minimizations as a function of a fixed internuclear distance between the reacting species.

\section{Results and Discussion}

\section{Generation of Phenylium Ions}

Direct electron ionization of chlorobenzene yielded mainly the molecular ion and a fragment at $m / z$ 77. It has been reported that isomeric $\mathrm{m} / z 77$ ions can be formed from the electron ionization of chlorobenzene [12]. These isomeric ions can be differentiated by their reactivity toward neutral chlorobenzene with phenylium ions being much more reactive. The energy barrier for ring opening has been determined to be $2.0 \pm 0.3 \mathrm{eV}$. Thus, to minimize the possibility of isomeric ions, $\mathrm{C}_{6} \mathrm{H}_{5}^{+}$was generated via MS/MS of the molecular ion.

To check for purity, the product ion at $m / z 77$ was isolated and allowed to react with neutral chlorobenzene. The exponential decay as a function of time indicated only one population of ion structures, which reacted with a rate constant of $1.47 \times 10^{-9} \mathrm{~cm}^{3}$ molecules ${ }^{-1} \mathrm{~s}^{-1}$. Average dipole orientation calculations gave a value of $1.733 \times 10^{-9} \mathrm{~cm}^{3}$ molecules ${ }^{-1} \mathrm{~s}^{-1}$ for the collision rate, which suggests that every collision is reactive. This is in contrast to an ICR study in which a rate constant of $3.8 \times 10^{-10} \mathrm{~cm}^{3}$ molecules ${ }^{-1} \mathrm{~s}^{-1}$ was determined [12]. This discrepancy may be due to the He bath gas used in the present experiment, which can collisionally stabilize a reaction complex that might otherwise just break apart back into reactants.

\section{Oxygen-Containing Neutrals}

$\mathbf{R}_{\mathbf{1}}=\mathbf{R}_{\mathbf{2}}=\mathbf{H}$. The ion-induced dipole interaction between the strongly electrophilic $\mathrm{C}_{6} \mathrm{H}_{5}^{+}$ion and $\mathrm{H}_{2} \mathrm{O}$ leads to the exclusive formation of a product ion at $m / z$ 95, $\left(\mathrm{C}_{6} \mathrm{H}_{7} \mathrm{O}^{+}\right)$a, as shown in eq 1 and $m / z$ 97, b, when $\mathrm{D}_{2} \mathrm{O}$ was used as the neutral molecule (eq 2):

$$
\begin{gathered}
\mathrm{C}_{6} \mathrm{H}_{5}^{+}+\mathrm{H}_{2} \mathrm{O} \rightarrow \underset{\text { a }}{\mathrm{C}_{6} \mathrm{H}_{5} \mathrm{OH}_{2}^{+}} \quad 100 \% \\
\mathrm{C}_{6} \mathrm{H}_{5}^{+}+\mathrm{D}_{2} \mathrm{O} \rightarrow \underset{\text { b }}{\mathrm{C}_{6} \mathrm{H}_{5} \mathrm{OD}_{2}^{+}} 100 \% \\
\end{gathered}
$$

Thermochemical calculations given in Table 1 show formation of the adduct to be exothermic by 65.5 $\mathrm{kcal} / \mathrm{mol}$. The loss of the hydrogen radical from the adduct to form the phenolic ion is endothermic by 13.6 $\mathrm{kcal} / \mathrm{mol}$ and is not observed (Table 1).

Selective isolation and collisional activation of a resulted in primarily the loss of $\mathrm{II}_{2} \mathrm{O}$, which indicates 
Table 1. Thermodynamic calculations for the reaction of $\mathrm{C}_{6} \mathrm{H}_{5}^{+}$with $\mathrm{H}_{2} \mathrm{O}, \mathrm{CH}_{3} \mathrm{OH}$, and $\left(\mathrm{CH}_{3}\right)_{2} \mathrm{O}$

\begin{tabular}{|c|c|c|c|c|}
\hline $\begin{array}{l}\text { Neutral } \\
\text { reactant }\end{array}$ & $\begin{array}{l}\text { Product } \\
\text { ion }\end{array}$ & $\begin{array}{c}\text { Neutral } \\
\text { loss }\end{array}$ & $\begin{array}{c}\Delta H_{r \times n} \\
(\mathrm{kcal} / \mathrm{mol})\end{array}$ & $\begin{array}{l}\% \text { of } \\
\text { total }\end{array}$ \\
\hline \multirow[t]{2}{*}{$\mathrm{H}_{2} \mathrm{O}$} & $\mathrm{C}_{6} \mathrm{H}_{5} \mathrm{OH}_{2}^{+}$ & - & -65.5 & 100 \\
\hline & $\mathrm{C}_{6} \mathrm{H}_{5} \mathrm{OH}^{+}$ & $\mathrm{H}^{-}$ & +13.6 & - \\
\hline \multirow[t]{11}{*}{$\mathrm{CH}_{3} \mathrm{OH}$} & $\mathrm{C}_{6} \mathrm{H}_{5} \mathrm{OH}\left(\mathrm{CH}_{3}\right)^{+}$ & - & -72.1 & 6 \\
\hline & $\mathrm{C}_{6} \mathrm{H}_{5} \mathrm{OH}^{+\cdot}$ & $\mathrm{CH}_{3}$ & -13.3 & 94 \\
\hline & $\mathrm{C}_{6} \mathrm{H}_{5} \mathrm{CH}_{2} \mathrm{OH}^{+\cdot}$ & $\mathrm{H}^{\cdot}$ & +3 & - \\
\hline & $\mathrm{C}_{6} \mathrm{H}_{5} \mathrm{OCH}_{3}^{+}$ & $\mathrm{H}^{\cdot}$ & +4 & - \\
\hline & $\mathrm{C}_{6} \mathrm{H}_{5} \mathrm{CH}_{3}^{+\cdot}$ & $\mathrm{OH}^{\circ}$ & +3.2 & - \\
\hline & $\mathrm{C}_{6} \mathrm{H}_{5} \mathrm{O}^{+}$ & $\mathrm{CH}_{4}$ & -30.9 & - \\
\hline & $\mathrm{C}_{6} \mathrm{H}_{5} \mathrm{CH}_{2}^{+}$ & $\mathrm{H}_{2} \mathrm{O}$ & -63.9 & - \\
\hline & $\mathrm{C}_{6} \mathrm{H}_{5} \mathrm{CHOH}^{+}$ & $\mathrm{H}_{2}$ & -64.1 & - \\
\hline & $\mathrm{C}_{6} \mathrm{H}_{5} \mathrm{OCH}_{2}^{+}$ & $\mathrm{H}_{2}$ & $-73.1^{\mathrm{a}}$ & - \\
\hline & $\mathrm{CH}_{2} \mathrm{OH}^{+}$ & $\mathrm{C}_{6} \mathrm{H}_{6}$ & -33.3 & - \\
\hline & $\mathrm{CH}_{2} \mathrm{OH}_{2}^{+}$ & $\mathrm{C}_{6} \mathrm{H}_{4}$ & +29.9 & - \\
\hline \multirow[t]{7}{*}{$\mathrm{CH}_{3} \mathrm{OCH}_{3}$} & $\mathrm{C}_{6} \mathrm{H}_{5} \mathrm{O}\left(\mathrm{CH}_{3}\right)_{2}^{+}$ & - & $-74.5^{a}$ & 17 \\
\hline & $\mathrm{C}_{6} \mathrm{H}_{5} \mathrm{OCH}_{3}^{+\cdot}$ & $\mathrm{CH}_{3}$ & -17.5 & 61 \\
\hline & $\mathrm{CH}_{3} \mathrm{OCH}_{2}^{+}$ & $\mathrm{C}_{6} \mathrm{H}_{6}$ & -48.5 & 22 \\
\hline & $\mathrm{C}_{6} \mathrm{H}_{5} \mathrm{OCH}_{2}^{+\cdot}$ & $\mathrm{CH}_{4}$ & $-95.1^{a}$ & - \\
\hline & $\mathrm{C}_{6} \mathrm{H}_{5} \mathrm{O}^{+}$ & $\mathrm{C}_{2} \mathrm{H}_{6}$ & -37.4 & 一 \\
\hline & $\mathrm{C}_{6} \mathrm{H}_{5} \mathrm{CH}_{2}^{+}$ & $\mathrm{CH}_{3} \mathrm{OH}$ & -58.5 & - \\
\hline & $\left(\mathrm{CH}_{3}\right)_{2} \mathrm{OH}^{+}$ & $\mathrm{C}_{6} \mathrm{H}_{4}$ & +19.7 & - \\
\hline
\end{tabular}

${ }^{a} \triangle H_{r \times n}$ based on MOPAC calculated heats of formation of the product ion.

that reaction (1) produces protonated phenol. A reference structure was generated by methane chemical ionization of phenol. CID of protonated phenol produced $\mathrm{C}_{6} \mathrm{H}_{5}^{+}$as the primary product, which supports the idea that the product ion a in eq 1 is oxygenprotonated phenol. In addition to the $\mathrm{H}_{2} \mathrm{O}$ loss that gives $\mathrm{C}_{6} \mathrm{H}_{5}^{+}$, a small product ion (approximately $10 \%$ relative intensity) at $m / z 67$ was observed in the CID MS/MS spectrum of both protonated phenol and a. This ion is ascribed to CO loss from ring-protonated phenol, which typically accounts for a small fraction of the protonated phenol ions [13-17]. This indicates that a small fraction of the ions either react by insertion of phenylium into an $\mathrm{O}-\mathrm{H}$ bond or transfer of a $\mathrm{H}$ atom from the oxygen to the ring after the complex is formed.

$\mathrm{D}_{2} \mathrm{O}$ reacted to form an ion at $m / z$ 97. A small intensity of $\mathrm{m} / z 95(\approx 5 \%)$ is attributed to residual $\mathrm{H}_{2} \mathrm{O}$ in the vacuum system and in $\mathrm{D}_{2} \mathrm{O}$. Upon isolation and collisional activation, $m / z 97$ formed product ions at $\mathrm{m} / \mathrm{z} 77(16 \%)$ and $78(84 \%)$ with a trace of $m / z 69$. These products, due to the losses of $\mathrm{D}_{2} \mathrm{O}(\mathrm{m} / \mathrm{z}$ $77)$ and DHO $(m / z 78)$, indicate some $\mathrm{H}^{-D}$ scrambling between the ring and the oxygen hydrogens. The presence of $m / z 69$ is attributed to $\mathrm{CO}$ loss from a small amount of ring-protonated ion. MS $/$ MS of $m / z$ 95 observed when $\mathrm{D}_{2} \mathrm{O}$ was the reactant gave $\mathrm{m} / z 77$ as the product ion. This confirmed that this ion was formed by the reaction of phenylium with residual
$\mathrm{H}_{2} \mathrm{O}$ and ruled out the possibility of the presence of $\mathrm{C}_{6} \mathrm{H}_{5} \mathrm{OD}^{+}$:

In addition to $m / z 97$ and 95 , ions at $m / z 98$ and 96 were observed at abundances greater than could be attributed to ${ }^{13} \mathrm{C}$. MS/MS of 96 yielded product ions at $m / z \quad 77$ and 78. Upon collisional activation, $m / z 98$ gave $m / z 79$ as a product ion. Although $m / z 78$ also would be expected, the very low parent ion intensity did not provide sufficient signal-to-noise ratio to observe this ion. These results indicate that some fraction of the collision complex dissociated back to reactants before collisional stabilization occurred. However, $\mathrm{H}-\mathrm{D}$ exchange between the ring and substituent could occur in the activated complex prior to dissociation back to the reactants. A single $\mathrm{H}-\mathrm{D}$ exchange between the ring and substituent protons prior to dissociation will result in the products $\mathrm{C}_{6} \mathrm{H}_{4} \mathrm{D}^{+}(\mathrm{m} / z$ 78) and HDO. This ion subsequently reacts with $\mathrm{H}_{2} \mathrm{O}$ and $\mathrm{D}_{2} \mathrm{O}$ to give the two product ions $\mathrm{C}_{6} \mathrm{H}_{4} \mathrm{DOH}_{2}^{+}$and $\mathrm{C}_{6} \mathrm{H}_{4} \mathrm{DOD}_{2}^{+}$at $m / z 96$ and 98 .

To probe the phenylium $-\mathrm{H}_{2} \mathrm{O}$ reaction surface, MOPAC calculations were done as a function of the distance between the charged $C$ of phenylium and oxygen. Figure 1 shows the calculated energy surface and the structure obtained at the minimum. For comparison purposes, the same calculation with methane is also shown. With methane the only possible reaction is insertion into a $\mathrm{C}-\mathrm{H}$ bond, which the calculation predicts. As can be seen, the reaction of phenylium 


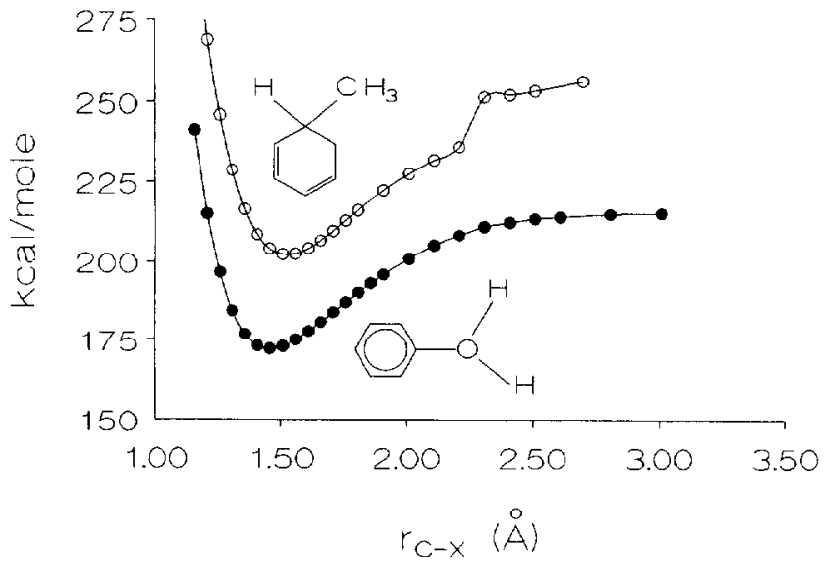

Figure 1. MOP $\triangle \mathrm{C}$ calculated potential surfaces for the reaction of $\mathrm{CH}_{4}$ and $\mathrm{H}_{2} \mathrm{O}$ with phenylium. The structures shown are those obtained at the minimum energy.

with $\mathrm{H}_{2} \mathrm{O}$ occurs with the oxygen lone pair and does not involve insertion into the $\mathrm{O}-\mathrm{H}$ bond. Starting either calculation with different orientations of the neutral with respect to the ion will lead to a small energy barrier as the two species approach each other. This barrier is the rotation required to align the ion and dipole in the case of $\mathrm{H}_{2} \mathrm{O}$ and to optimize the orientation for the bond insertion in $\mathrm{CH}_{4}$ (this actually can be seen in the series of calculations shown in Figure 1).

$\mathbf{R}_{\mathbf{1}}=\mathbf{C H}_{3} \mathbf{R}_{\mathbf{2}}=\mathbf{H} . \quad$ Almost exclusive demethylation occurred in the reaction of phenylium with methanol; only a small amount of the collisionally stabilized adduct ion d was observed (reactions 3 and 4):

$$
\begin{aligned}
\mathrm{C}_{6} \mathrm{H}_{5}^{+} & +\mathrm{CH}_{3} \mathrm{OH} \\
& \rightarrow \mathrm{C}_{6} \mathrm{H}_{5} \mathrm{OH}^{+\cdot}+\mathrm{CH}_{3} \quad 94 \% \\
& \rightarrow \underset{6}{\mathrm{C}} \mathrm{C}_{6} \mathrm{H}_{5} \mathrm{OH}\left(\mathrm{CH}_{3}\right)^{+} \\
\quad &
\end{aligned}
$$

The major product ion at $m / z$ is due to the elimination of $\mathrm{CH}_{3}^{-}$by the cleavage of the $\mathrm{O}-\mathrm{C}$ bond from the excited intermediate $\mathrm{C}_{6} \mathrm{H}_{5} \mathrm{OH}\left(\mathrm{CH}_{3}\right)^{+}$(vide infra). It seems logical to assume that $\mathrm{c}$ represents a phenol molecular ion. Confirmation of this was obtained when selective isolation and subsequent CID of c were compared with the CID spectrum of the phenol molecular ion generated by electron ionization of phenol. Both CID mass spectra recorded under identical conditions gave primarily a product ion at $m / z 66$ due to decarbonylation. In an $\mathrm{MS}^{3}$ experiment $\mathrm{m} / \mathrm{z} 66$ dissociates to $m / z 65$.

The adduct ion d $\left(\mathrm{C}_{6} \mathrm{H}_{5} \mathrm{OH}\left(\mathrm{CH}_{3}\right)^{+}\right)$at $m / z 109$ would most likely have the structure of either protonated anisole or protonated benzyl alcohol, although protonated cresol is also a possibility. One structure of protonated anisole (oxygen-protonated) would be formed if phenylium reacts with the oxygen lone pair electrons, whereas insertion between the $\mathrm{O}-\mathrm{H}$ bond would generate an isomeric structure (ipso-protonated). A protonated benzyl alcohol structure (ipsoprotonated) would be formed if the phenylium inserts into a $\mathrm{C}-\mathrm{H}$ bond like it does when it reacts with methane. The experimental heat of formation of protonated benzyl alcohol is $4 \mathrm{kcal} / \mathrm{mol}$ greater than that of protonated anisole, as determined by proton affinity measurements [11]. However, the products formed from the reaction of methanol with phenylium may not have the same structure as the protonated species. MOPAC calculations of the three possible geometries predict a heat of formation for the ipso-protonated benzyl alcohol that is $15 \mathrm{kcal} / \mathrm{mol}$ lower than $\mathrm{O}$ protonated anisole, which is $5 \mathrm{kcal} / \mathrm{mol}$ lower than ipso-protonated anisole. Further MOPAC calculations, with ring-protonated anisole, show that ortho and para protonation give results within $4 \%$ of the experimental results whereas the benzyl alcohol calculations are within $2 \%$ of the experimental results. From consideration of the energies, it might be expected that the ipso-protonated benzyl alcohol would be the favored product from the reaction of methanol and phenylium. However, the calculations do not take into account any energy barriers that might exist to insertion into the $\mathrm{C}-\mathrm{H}$ bond, which may be large to overcome the stabilization of the ion-dipole interaction as the reactants approach.

Although the adduct ion $\mathbf{d}$ was only a small fraction of the reaction products there was sufficient intensity to perform MS/MS experiments. Upon CID, $\mathbf{d}$ dissociated to a product ion at $\mathrm{m} / z$ 94 (loss of $\mathrm{CH}_{3}{ }_{3}$ ) with

\begin{tabular}{|c|c|c|c|c|c|c|c|}
\hline \multirow[b]{2}{*}{ Parent ion $(m />109)$} & \multicolumn{7}{|c|}{ Product ions (relative intensity) } \\
\hline & 108 & 107 & 94 & 91 & 81 & 80 & 79 \\
\hline Anisole $+\mathrm{H}^{+\mathrm{a}}$ & 40 & & 44 & & 8 & & 8 \\
\hline Ben $\angle y l$ alcohol $+\mathrm{H}^{+\mathrm{b}}$ & 50 & & & 25 & 25 & & \\
\hline Cresol $+\mathrm{H}^{+\mathbf{a}}$ & & 37 & & 28 & 25 & & \\
\hline Phenylium-methanol adduct (d) & 25 & & 50 & & 25 & & \\
\hline
\end{tabular}
lower intensity product ions at $\mathrm{m} / z$ 81 (loss of CO) and 108 (loss of $\mathrm{H}^{\circ}$ ) as shown in Table 2. The loss of

Table 2. 
$\mathrm{CH}_{3}$ indicates that the ipso-protonated benzyl alcohol is not formed because there are no methyl groups in this structure. Conversely, loss of $\mathrm{CH}_{3}$ should be a rather facile loss from protonated anisole.

For comparison, protonated anisole and protonated cresol were generated by methane chemical ionization and protonated benzyl alcohol was generated by selfchemical ionization. CID spectra of each reference ion were obtained to compare with that of $\mathbf{d}$ (Table 2). The protonated $o^{-}, p^{-}$, and $m$-cresols gave identical MS/MS spectra; each dissociated to give product ions at $\mathrm{m} / \mathrm{z}$ 81, 91, and 107. Protonated anisole gave two major product ions, at $m / z 94$ and 108, with lower intensities products at $m / z 81$ and 79 . Protonated benzyl alcohol gave three products, at $m / z 80,91$, and 108. Although the CID spectrum of $\mathbf{d}$ is not identical with any of the reference CID spectra, these results indicated that $d$ most likely has the structure of protonated anisole. The major product ion observed from dissociation of $\mathbf{d}$ is $m / z$ 94, which is observed only from protonated anisole. Although $m / z 79$ is not detected in the CID spectrum of $d$, this may be due to lack of sensitivity because the parent ion $\mathbf{d}$ is of low intensity. The relative intensity of $m / z 108$ is greater for protonated anisole than for $\mathbf{d}$, whereas $m / z 81$ has a lower relative intensity for anisole than for $\mathbf{d}$. This may be due to a different distribution of ions (i.e., sites of protonation) generated via chemical ionization versus the phenylium-methanol ion-molecule reaction. This seems likely given the MOPAC calculations, which indicate that ring protonation of anisole is the thermodynamically favored site by $17 \mathrm{kcal} / \mathrm{mol}$ over the oxygen-protonated species that would be the initial adduct structure.

The formation of the phenol molecular ion and protonated anisole is consistent with results obtained in high pressure radiolysis experiments [3] and high pressure $\mathrm{Cl}$ [4]. It is worth noting that for the high pressure chemical ionization, MS/MS with a triple quadrupole mass spectrometer was used to identify the structure. CID MS/MS of protonated cresols in the triple quadrupole gave $m / z \quad 94$ as the base peak, whereas the base peak for protonated anisole was $m / z$ 77. The same results also have been observed for high energy CID in a sector instrument [16]. This is in contrast with the present results in which $\mathrm{m} / \mathrm{z} 77$ is not observed and $m / z 94$ is only observed for protonated anisole. This apparent discrepancy suggests that methyl loss by cleavage of the $\mathrm{O}-\mathrm{C}$ bond in anisole is a lower energy process than methyl loss by cleavage of a $\mathrm{C}-\mathrm{C}$ bond in cresols. In the higher energy and faster time frame for dissociation in the triple quadrupole and sector CID experiments the higher energy $\mathrm{C}-\mathrm{C}$ methyl loss may be kinetically competitive with other dissociation pathways, whereas it is not in the lower energy longer time frame CID experiment in the quadrupole ion trap. In this case then, the quadrupole ion trap provides better isomer differentiation than higher energy CID methods.

In the ion-molecule reaction process for methanol the electrophilic phenylium ion appears to attack the lone electron pair on oxygen (based on the experimental results and calculations of the energy surface as previously described for $\mathrm{H}_{2} \mathrm{O}$ ). The interaction between the reactants forms an excited intermediate that rapidly undergoes simple cleavage of the $\mathrm{C}-\mathrm{O}$ bond or relaxes due to third body collisions to form a stabilized complex. Table 1 shows that alternative $\mathrm{H}^{\text {* }}$ loss from either protonated anisole or benzyl alcohol is an endothermic process like $\mathrm{H}^{\cdot}$ loss from the phenylium $-\mathrm{H}_{2} \mathrm{O}$ adduct. However, also listed in Table 1 are a number of other products that could be formed by exothermic processes that involve the loss of small neutral molecules. Of particular note is the loss of $\mathrm{H}_{2}$ to give $\mathrm{C}_{6} \mathrm{H}_{5} \mathrm{OCH}_{2}^{+}$. These reaction products are just as stable as the adduct, but this reaction is not observed. (Actually these products are more stable than the adduct that is formed because the calculated heat of formation of the oxygen-protonated anisole is 18 $\mathrm{kcal} / \mathrm{mol}$ greater than the lowest energy form, which is what should be measured experimentally.) The fact that $\mathrm{H}_{2}$ loss is not observed may be the result that loss of $\mathrm{H}_{2}$ from the oxygen-protonated anisole adduct structure would occur by a symmetry-forbidden 1,2 elimination [18]. Alternatively, $\mathrm{H}_{2}$ loss may not be kinetically competitive with the simple cleavage of $\mathrm{CH}_{3}$. It also may be that there is sufficient energy in the initial adduct to allow proton migration from the oxygen to the benzene ring. Once on the ring, the proton could easily migrate to the most stable site, the para position, which would then preclude $\mathrm{H}_{2}$ loss.

Reactions with the $\mathrm{O}$-deuterated and perdeuterated analogs follow a similar pattern that generates $\mathrm{C}_{6} \mathrm{H}_{5} \mathrm{OD}^{+\cdot}$ as the major product ion (reactions 5-8):

$$
\begin{array}{rl}
\mathrm{C}_{6} \mathrm{H}_{5}^{+}+\mathrm{CH}_{3} \mathrm{OD} & \rightarrow \mathrm{C}_{6} \mathrm{H}_{5} \mathrm{OD}^{+\cdot}+\mathrm{CH}_{3} \\
\mathbf{e} & \rightarrow \mathrm{C}_{6} \mathrm{H}_{5} \mathrm{OD}\left(\mathrm{CH}_{3}\right)^{+} \\
\mathbf{f} & 7 \% \\
\mathrm{C}_{6} \mathrm{H}_{5}^{+}+\mathrm{CD}_{3} \mathrm{OD} & \rightarrow \mathrm{C}_{6} \mathrm{H}_{5} \mathrm{OD}^{+\cdot}+\mathrm{CD}_{3} \\
\mathbf{g} & 95 \% \\
& \rightarrow \mathrm{C}_{6} \mathrm{H}_{5} \mathrm{OD}\left(\mathrm{CD}_{3}\right)^{+} \\
\mathbf{h} & 5 \%
\end{array}
$$

MS/MS of the deuterated phenol ions $\mathbf{e}$ and $\mathbf{g}$ gave a major product ion at $m / z 67\left(\mathrm{C}_{5} \mathrm{H}_{5} \mathrm{D}^{+\cdot}\right)$. $\mathrm{MS}^{3}$ reactions produced primarily the $m / z 66$ ion and, to a lesser degree, $m / z$ 65. Minor amounts of $m / z 94$ were observed in the mass spectrum due to $\mathrm{CH}_{3} \mathrm{OH}$ impurity in the samples. MS/MS reactions confirmed this impurity by producing $m / z 66$ (MS/MS) and $m / z 65$ $\left(\mathrm{MS}^{3}\right)$ were produced on dissociation. The reaction with $\mathrm{CD}_{3} \mathrm{OD}$ also produces ions at $m / z$ 96. This low 
intensity peak is presumably due to a single $\mathrm{H}-\mathrm{D}$ exchange between the ring and the substituent protons, analogous to the previously discussed exchange with $\mathrm{D}_{2} \mathrm{O}$.

$\mathbf{R}_{1}=\mathbf{R}_{2}=\mathbf{C H}_{3}$. In the reaction of phenylium ion with dimethylether, the major product ion was due to the loss of $\mathrm{CH}_{3}^{-}$(reactions 9-11):

$$
\begin{array}{rlr}
\mathrm{C}_{6} \mathrm{H}_{5}^{+} & +\mathrm{CH}_{3} \mathrm{OCH}_{3} & \\
& \rightarrow \mathrm{C}_{6} \mathrm{H}_{5} \mathrm{O}^{\left.-C_{3}\right)_{2}^{+}} & 17 \% \\
& \rightarrow \mathrm{C}_{6} \mathrm{H}_{5} \mathrm{OCH}_{3}^{+}+\mathrm{CH}_{3} & 61 \% \\
& \rightarrow \mathrm{CH}_{3} \mathrm{OCH}_{2}^{+}+\mathrm{C}_{6} \mathrm{H}_{6} & 22 \%
\end{array}
$$

In this reaction a higher degree of collisional stabilization of the adduct relative to the fragment was observed than with methanol. This possibly could be due to a larger collision cross section (faster stabilization) and the larger number of degrees of freedom (longer lifetime for the activated complex). The inductive effect of the $\mathrm{CH}_{3}$ group also could contribute toward stronger binding with the phenylium cation. In addition to formation of an ion-molecule complex, the phenylium can abstract a hydride from the neutral dimethylether.

The structure of $\mathrm{C}_{6} \mathrm{H}_{5} \mathrm{OCH}_{3}^{+\cdot} \mathrm{i}$ should most likely be that of anisole. To confirm this, MS/MS spectra of anisole and the isomeric cresol molecular ions were obtained. The MS/MS spectrum of anisole showed a product ion at $m / z 78\left(\mathrm{C}_{6} \mathrm{H}_{6}^{+\cdot}\right)$ due to the elimination of formaldehyde from the molecular ion, whereas cresol gave $m / z 80$ due to decarbonylation. The MS/MS spectrum of $\mathbf{i}$, under the same conditions as used for anisole, gave a product ion at $m / z 78$, which supports the conclusion that the structure of $i$ is anisole.

Table 1 includes thermodynamic calculations for several possible reaction channels. Again, radical loss is observed rather than neutral loss even though the latter reactions are thermodynamically more favorable. For example, loss of $\mathrm{CH}_{4}$ would be an even more exothermic process than adduct formation. Again, this would require a 1,2 elimination. Because the energy barrier to this reaction most likely would not exceed the initial internal energy of the complex, collisional stabilization and $\mathrm{CH}_{3}^{-}$loss must be kinetically favored.

\section{Nitrogen-Containing Neutrals}

$\mathbf{R}_{\mathbf{1}}=\mathbf{R}_{\mathbf{2}}=\mathbf{R}_{3}=\mathbf{H}$. The reaction with $\mathrm{NH}_{3}$ and $\mathrm{ND}_{3}$ gave predominantly the intact adduct ion, but the loss of hydrogen, to form $\mathrm{m} / \mathrm{z} 93$ or 96 , also was observed (reactions 12-15):

$$
\begin{aligned}
& \mathrm{C}_{6} \mathrm{H}_{5}^{+}+\mathrm{NH}_{3} \rightarrow \mathrm{C}_{6} \mathrm{H}_{5} \mathrm{NH}_{3}^{+} \\
& \text {j } \\
& \rightarrow \mathrm{C}_{6} \mathrm{H}_{7} \mathrm{~N}^{+\cdot}+\mathrm{H}^{.} \\
& \mathbf{k}
\end{aligned}
$$

$$
\begin{aligned}
& \mathrm{C}_{6} \mathrm{H}_{5}^{+}+\mathrm{ND}_{3} \rightarrow \mathrm{C}_{6} \mathrm{H}_{5} \mathrm{D}_{3} \mathrm{~N}^{+} \quad 90 \% \\
& 1 \\
& \rightarrow \mathrm{C}_{6} \mathrm{H}_{4} \mathrm{D}_{3} \mathrm{~N}^{+\cdot}+\mathrm{H}^{\cdot} \quad 10 \% \\
& \text { m }
\end{aligned}
$$

The adduct ion $\mathbf{j}$ was isolated and dissociated. The resulting MS/MS spectrum was compared with the MS/MS spectrum of protonated aniline (self-CI). Both spectra showed the presence of two processes, $\mathrm{H}^{*}$ loss and $\mathrm{NH}_{3}$ loss, although in different ratios. However, aniline protonation has been shown to occur at both the ring and the substituent [16, 17, 19-23] and because the adduct initially is substituent-protonated, differences in the ratio of $\mathrm{NH}_{3}$ to $\mathrm{H}^{\prime}$ loss probably indicate the presence of different ratios of ring versus substituent protonation. These results support the idea that the structure of $\mathbf{j}$ is that of protonated aniline. The loss of $\mathrm{NH}_{3}$ is a typical feature of the $\mathrm{CI}$ spectrum of primary amines.

The ion $\mathbf{k}$ was isolated and subjected to CID for comparison with the CID spectrum of the aniline molecular ion. Both ions show a predominant loss of 27 mass units (HNC). This is a well known low energy dissociation reaction pathway for the aniline molecular ion [24-26].

$\mathrm{ND}_{3}$ showed analogous reactions; however, hydrogen loss was preferentially favored over deuterium loss at the helium pressure used here (reactions 14 and 15). Deuterium loss was observed only at lower pressures. Isolation and dissociation of 1 gave product ions at $m / z 78,79,80,95$, and 96 . These are due to either $\mathrm{N}(\mathrm{H}, \mathrm{D})_{3}$ loss or $\mathrm{H}(\mathrm{D})$ loss. This dissociation pattern is similar to the $\mathrm{CID}$ of $\mathrm{C}_{6} \mathrm{H}_{5} \mathrm{NH}_{3}^{+}$. These results indicate rapid exchange between substituent and ring hydrogen (deuterium). Recent experiments in the collision cell of a BEqQ instrument show evidence for substantial exchange between $\mathrm{N}$-protonated ions and $\mathrm{ND}_{3}$ [27]. However, whether there is subsequent $\mathrm{H}-\mathrm{D}$ interchanges between ring and substituent hydrogens in that study is not clear. Other studies indicate that ring-substituent hydrogen exchange does not occur [22], although it is believed that this is a function of the internal energy of the protonated aniline (Ranasinghe, Y. A.; Glish, G. L., in preparation).

The presence of ions at $\mathrm{m} / z 98$ and 99 in the mass spectrum provides further evidence of ringsubstituent $\mathrm{H}-\mathrm{D}$ exchange. As in the reaction with water, the phenylium-ammonia ion-molecule adduct can form, exchange $\mathrm{H}-\mathrm{D}$ between the ion and neutral, and then dissociate back to reactants. CID of $\mathrm{m} / z 98$ and 99 produced product ions at $\mathrm{m} / z 78,79,80,81$ and $79,80,81$, respectively. These product ions further substantiate the occurrence of rapid $\mathrm{H}-\mathrm{D}$ scrambling in the adduct. Further details about the energy barriers involved in the exchange process along with the isotopic effects on dissociation will be reported elsewhere. 
$\mathbf{R}_{1}=\mathbf{C H}_{3}, \mathbf{R}_{2}=\mathbf{R}_{3}=\mathbf{H}$. In the reaction of methylamine with phenylium (equations 16-18),

$$
\begin{aligned}
& \mathrm{C}_{6} \mathrm{H}_{5}^{+}+\mathrm{CH}_{3} \mathrm{NH}_{2} \rightarrow \mathrm{C}_{6} \mathrm{H}_{5} \mathrm{NH}_{2}\left(\mathrm{CH}_{3}\right)^{+} \quad 4 \% \\
& \rightarrow \mathrm{C}_{6} \mathrm{H}_{5} \mathrm{NH}_{2}^{+\cdot}+\mathrm{CH}_{3} \quad 23 \% \\
& \rightarrow \mathrm{CH}_{3} \mathrm{NH}_{3}^{+}+\mathrm{C}_{6} \mathrm{H}_{4} \quad 73 \%
\end{aligned}
$$

proton transfer competes effectively with methyl loss and adduct ion formation due to the high proton affinity of $\mathrm{CH}_{3} \mathrm{NH}_{2}(\mathrm{PA}=214.1 \mathrm{kcal} / \mathrm{mol})$ relative to the proton affinity of benzyne $(\mathrm{PA}=211.4 \mathrm{kcal} / \mathrm{mol}$ ) [11]. Although the predominant reaction was proton transfer, hydride transfer is a much more exothermic reaction (Table 3), but it was not observed. A possible explanation for the lack of hydride transfer may involve the orientation of the ion-molecule complex. The strong ion-dipole interaction may orient the incoming amine such that the methyl group, from which the hydride must be transferred, does not approach the vacant $s p^{2}$ orbital prior to the formation of the $\mathrm{C}-\mathrm{N}$ bond. Proton transfer can still occur in the other direction because a hydrogen on a carbon adjacent to the reaction center would be involved.

With respect to the competition between the formation of the adduct and proton transfer, for the reaction of alkyl ions with amines it has been proposed that different "structures" of the adduct are responsible for the two reactions [28]. A longer range electrostatic complex is suggested as the reacting form for proton transfer, which is competitive with collisional stabilization to a "tighter" complex, which then can be stabilized as the ion-molecule product. Such a mechanism might explain why proton transfer is the major reaction channel observed for phenylium even though it is the least exothermic channel.

For those reactions that form the ion-molecule complex, as with the oxygen-containing species, loss of a hydrogen from methylamine-phenylium adduct is endothermic and was not observed. The only fragment observed was loss of methyl. MS/MS data showed that the product ion due to $\mathrm{CH}_{3}$ loss (reaction 17) has the aniline structure. Following the same trend as the homologs, loss of small neutral molecules, such as $\mathrm{H}_{2}$ loss, which are the most exothermic reactions after the adduct formation, were not observed. Analogous to the oxygen species, this would be a 1,2 elimination, which is either kinetically unfavorable or has a high energy transition state due to orbital symmetry considerations.

$\mathbf{R}_{1}=\mathbf{R}_{2}=\mathbf{C H}_{3}, \mathbf{R}_{\mathbf{1}}=\mathbf{H}$. Similar trends were observed for the reactions of dimethylamine with

\begin{tabular}{|c|c|c|c|c|}
\hline $\begin{array}{l}\text { Neutral } \\
\text { reagent }\end{array}$ & $\begin{array}{l}\text { Product } \\
\text { ion }\end{array}$ & $\begin{array}{c}\text { Neutral } \\
\text { loss }\end{array}$ & $\begin{array}{c}\Delta H_{r \times n} \\
(\mathrm{kcal} / \mathrm{mol})\end{array}$ & $\begin{array}{l}\% \text { of } \\
\text { total }\end{array}$ \\
\hline \multirow[t]{3}{*}{$\mathrm{NH}_{3}$} & $\mathrm{C}_{6} \mathrm{H}_{5} \mathrm{NH}_{3}^{+}$ & - & -81.3 & 90 \\
\hline & $\mathrm{C}_{6} \mathrm{H}_{5} \mathrm{NH}_{2}^{+} \cdot$ & $\mathrm{H}^{\cdot}$ & -8.2 & 10 \\
\hline & $\mathrm{NH}_{4}^{+}$ & $\mathrm{C}_{6} \mathrm{H}_{4}$ & +7.7 & - \\
\hline \multirow[t]{6}{*}{$\mathrm{CH}_{3} \mathrm{NH}_{2}$} & $\mathrm{C}_{6} \mathrm{H}_{5} \mathrm{NH}_{2}\left(\mathrm{CH}_{3}\right)^{+}$ & - & -95.8 & 4 \\
\hline & $\mathrm{C}_{6} \mathrm{H}_{5} \mathrm{NH}_{2}^{+}$ & $\mathrm{CH}_{3}$ & -31 & 23 \\
\hline & $\mathrm{CH}_{3} \mathrm{NH}_{3}^{+}$ & $\mathrm{C}_{6} \mathrm{H}_{4}$ & -2.8 & 73 \\
\hline & $\mathrm{C}_{6} \mathrm{H}_{5} \mathrm{NH}\left(\mathrm{CH}_{2}\right)^{+}$ & $\mathrm{H}_{2}$ & -60.9 & - \\
\hline & $\mathrm{CH}_{2} \mathrm{NH}_{2}^{+}$ & $\mathrm{C}_{6} \mathrm{H}_{0}$ & -43 & - \\
\hline & $\mathrm{C}_{6} \mathrm{H}_{5} \mathrm{NH}\left(\mathrm{CH}_{3}\right)^{+\cdot}$ & $\mathrm{H}^{\cdot}$ & +7.3 & - \\
\hline \multirow[t]{7}{*}{$\left(\mathrm{CH}_{3}\right)_{2} \mathrm{NH}$} & $\mathrm{C}_{6} \mathrm{H}_{5} \mathrm{NH}\left(\mathrm{CH}_{3}\right)_{2}^{+}$ & - & -98.9 & 2 \\
\hline & $\mathrm{C}_{6} \mathrm{H}_{5} \mathrm{NH}\left(\mathrm{CH}_{3}\right)^{+\cdot}$ & $\mathrm{CH}_{3}$ & -41.1 & 14 \\
\hline & $\left(\mathrm{CH}_{3}\right)_{2} \mathrm{NH}_{2}^{+}$ & $\mathrm{C}_{6} \mathrm{H}_{1}$ & -8.9 & 84 \\
\hline & $\mathrm{CH}_{3} \mathrm{NH}\left(\mathrm{CH}_{2}\right)^{+}$ & $\mathrm{C}_{6} \mathrm{H}_{6}$ & -79.1 & 3 \\
\hline & $\mathrm{C}_{6} \mathrm{H}_{5} \mathrm{NH}\left(\mathrm{CH}_{2}\right)^{+}$ & $\mathrm{CH}_{4}$ & -96.0 & - \\
\hline & $\mathrm{C}_{6} \mathrm{H}_{5} \mathrm{~N}\left(\mathrm{CH}_{3}\right) \mathrm{CH}_{2}^{+}$ & $\mathrm{H}_{2}$ & -70.4 & - \\
\hline & $\mathrm{C}_{6} \mathrm{H}_{5} \mathrm{~N}\left(\mathrm{CH}_{3}\right)_{2}^{+\cdot}$ & $\mathrm{H}^{-}$ & -24.8 & - \\
\hline \multirow[t]{6}{*}{$\left(\mathrm{CH}_{3}\right)_{3} \mathrm{~N}$} & $\mathrm{C}_{6} \mathrm{H}_{5} \mathrm{~N}\left(\mathrm{CH}_{3}\right)_{3}^{+}$ & - & $-87.2^{a}$ & 4 \\
\hline & $\mathrm{C}_{6} \mathrm{H}_{5} \mathrm{~N}\left(\mathrm{CH}_{3}\right)_{2}^{+\cdot}$ & $\mathrm{CH}_{3}$ & -40.8 & 2 \\
\hline & $\left(\mathrm{CH}_{3}\right)_{3} \mathrm{NH}^{+}$ & $\mathrm{C}_{6} \mathrm{H}_{4}$ & -13.6 & 54 \\
\hline & $\left(\mathrm{CH}_{3}\right)_{2} \mathrm{NCH}_{2}^{\prime}$ & $\mathrm{C}_{6} \mathrm{H}_{6}$ & -85.8 & 32 \\
\hline & $\left(\mathrm{CH}_{3}\right)_{3} \mathrm{~N}^{-}$ & $\mathrm{C}_{6} \mathrm{H}_{5}^{\cdot}$ & -9.6 & 8 \\
\hline & $\mathrm{C}_{6} \mathrm{H}_{5} \mathrm{~N}\left\langle\mathrm{CH}_{3}\right) \mathrm{CH}_{2}^{+}$ & $\mathrm{CH}_{4}$ & -88.2 & - \\
\hline
\end{tabular}

Table 3. Thermodynamic calculations for the reaction of $\mathrm{C}_{6} \mathrm{H}_{5}^{+}$with $\mathrm{NH}_{3}, \mathrm{CH}_{3} \mathrm{NH}_{2},\left(\mathrm{CH}_{3}\right)_{2} \mathrm{NH}$, and $\left(\mathrm{CH}_{3}\right)_{3} \mathrm{~N}$

${ }^{a} \triangle H_{r \times n}$ based on MOPAC calculated heats of formation for the product ion. 
phenylium (equations 19-22) as observed for methylamine:

$$
\begin{array}{rlr}
\mathrm{C}_{6} \mathrm{H}_{5}^{+} & +\left(\mathrm{CH}_{3}\right)_{2} \mathrm{NH} & \\
& \rightarrow \mathrm{C}_{6} \mathrm{H}_{5} \mathrm{NH}\left(\mathrm{CH}_{3}\right)_{2}^{+} & 2 \% \\
& \rightarrow \mathrm{C}_{6} \mathrm{H}_{5} \mathrm{NH}\left(\mathrm{CH}_{3}\right)^{+-}+\mathrm{CH}_{3} \cdot & 14 \% \\
& \rightarrow\left(\mathrm{CH}_{3}\right)_{2} \mathrm{NH}_{2}^{+}+\mathrm{C}_{6} \mathrm{H}_{4} & 81 \% \\
& \rightarrow \mathrm{CH}_{3} \mathrm{NH}\left(\mathrm{CH}_{2}\right)^{+}+\mathrm{C}_{6} \mathrm{H}_{6} & 3 \%
\end{array}
$$

The major reaction pathways were the proton transfer (dimethylamine $\mathrm{PA}=220.6 \mathrm{kcal} / \mathrm{mol}$ ) [11] and $\mathrm{CH}_{3}$. loss. The higher dimethylamine proton affinity versus methylamine is reflected in the higher abundance of the proton transfer reaction for dimethylamine. A small amount of hydride transfer was observed in the reaction with dimethylamine, whereas it is again a much more exothermic reaction channel than proton transfer. The observation of hydride transfer probably is a result of the ion-dipole interaction being weaker for the phenylium-dimethylamine adduct versus the phenylium-methylamine adduct, and the additional methyl group increases the probability of a favorable orientation for hydride transfer.

Dissociation of the intact adduct can occur by either methyl or hydrogen loss, with the former being more exothermic (Table 3). For these competitive fragmentations only methyl loss was observed. It has been shown in previous work that, even when the $\mathrm{H}^{*}$ loss channel is the more energetically favored reaction, $\mathrm{CH}_{3}$ loss is observed due to angular momentum considerations $[29,30]$. These ion-molecule complexes should have a relatively large angular momentum. Thus, perhaps similar considerations are appropriate for this system. Loss of $\mathrm{H}_{2}$ or $\mathrm{CH}_{4}$ to form immonium ions are both more exothermic reaction channels than methyl loss, but neither was observed. Again this suggests either kinetic barriers or high energy transition state energies due to orbital symmetry. The lack of $\mathrm{H}_{2}$ or $\mathrm{CH}_{4}$ loss is consistent with previous quadrupole ion trap MS/MS spectra of protonated $N, N$-dimethylamine (Glish, G. L.; McLuckey, S. A., unpublished results).

$\mathbf{R}_{1}=\mathbf{R}_{\mathbf{2}}=\mathbf{R}_{\mathbf{1}}=\mathbf{C H}_{3}$. Trimethylamine has the highest proton affinity [ $\left.\mathrm{PA}\left(\mathrm{CH}_{3}\right)_{3} \mathrm{~N}=225.1 \mathrm{kcal} / \mathrm{mol}\right]$ [11] and the reactions included but were not limited to proton transfer and methyl loss (reactions 23-27):

$$
\begin{array}{rlr}
\mathrm{C}_{6} \mathrm{H}_{5}^{+} & +\left(\mathrm{CH}_{3}\right)_{3} \mathrm{~N} \\
& \rightarrow \mathrm{C}_{6} \mathrm{H}_{5} \mathrm{~N}\left(\mathrm{CH}_{3}\right)_{3}^{+} & 4 \% \\
& \rightarrow \mathrm{C}_{6} \mathrm{H}_{5} \mathrm{~N}_{\left(\mathrm{CH}_{3}\right)_{2}^{+}+\mathrm{CH}_{3}} & 2 \% \\
& \rightarrow \mathrm{HN}\left(\mathrm{CH}_{3}\right)_{3}^{+}+\mathrm{C}_{6} \mathrm{H}_{4} & 54 \% \\
& \rightarrow\left(\mathrm{CH}_{3}\right)_{2} \mathrm{NCH}_{2}^{+}+\mathrm{C}_{6} \mathrm{H}_{6} & 32 \% \\
& \rightarrow \mathrm{N}\left(\mathrm{CH}_{3}\right)_{3}^{+}+\mathrm{C}_{6} \mathrm{H}_{5} & 8 \%
\end{array}
$$

Hydride abstraction was a more prominent reaction channel but still less than the less exothermic proton transfer reaction (Table 3). This is in keeping with the trend for the lower methyl homologs. Again, the ion-dipole strength has decreased and there is greater probability of a methyl group being in the appropriate orientation to transfer a hydride.

Trimethylamine showed a much greater degree of adduct ion versus fragment ion, compared to the lower homologs. This could be due to reasons cited for the oxygen-containing neutrals. Once again the thermodynamically most favored fragmentation pathway-loss of methane-is not observed. This is in contrast to previous results in which $\mathrm{CII}_{4}$ loss was observed in the laser desorption mass spectrum and MS/MS spectrum of trimethylphenylammonium [31].

\section{Conclusion}

The reactions of phenylium with $R_{1} R_{2} O$ and $R_{1} R_{2} R_{3} N$, in which $\mathrm{R}=\mathrm{H}$ or $\mathrm{CH}_{3}$ show many similarities. Experimental and theoretical results indicate that these neutrals interact with phenylium through lone pair electrons, even when bond insertion would form a more stable product. For $\mathrm{R}=\mathrm{H}$, mainly intact adduct ions are observed. There are no exothermic fragmentation pathways for the $\mathrm{H}_{2} \mathrm{O}$ adduct whereas loss of $\mathrm{H}^{\text {* }}$ is about $8 \mathrm{kcal} / \mathrm{mol}$ exothermic for the ammonia adduct. Under the experimental conditions of the quadrupole ion trap the $\mathrm{NH}_{3}$ adduct can be stabilized readily so only $10 \%$ of the $\mathrm{NH}_{3}$ adduct undergoes loss of $\mathrm{H}$ :

Replacement of an $\mathrm{H}$ with $\mathrm{CH}_{3}$ provides a new, more favorable fragmentation pathway - methyl loss. The amount of methyl loss relative to intact adduct decreases with increasing numbers of methyl groups. This likely results from longer-lived adduct ions, due to an increase in the number of degrees of freedom. The longer-lived adducts can then undergo increased collisional stabilization in the quadrupole ion trap. Surprisingly, small neutral losses are not observed from the excited adduct, even though these processes are more exothermic than the methyl loss. This may reflect the slower kinetics of such processes or high energy transition states due to orbital symmetry considerations. For the amines, proton transfer to form the protonated amine and benzyne is a dominant pathway. Hydride transfer, although more exothermic than proton transfer, is much less prominent, possibly due to the long range ion-dipole stabilization as the reactants approach. This long range interaction reduces the probability of favorable orientation for hydride transfer.

\section{References}

1. Speranza, M.; Sefcik, M. D.; Henis, J. M. S.; Gaspar, P. P. I. Am. Chem. Soc. 1977, 99, 5583.

2. I Iart, K. J.; McLuckey, S. A.; Glish, G. L. Proceedings of the 40th ASMS Conference on Mass Spectrometry and Allied Topics; Washington, DC, 1992; p 1187. 
3. Angelini, G.; Fornarini, S.; Speranza, M. I. Am. Chem. Soc. 1982, 104, 4773.

4. Dolnikowski, G. G.; Allison, J.; Watson, T. Org. Mass Spectrom. 1990, 25, 119.

5. Hart, K. J.; McLuckey, S. A.; Glish, G. L. I. Am. Soc. Mass Spectrom. 1992, 3, 549.

6. Stafford, G. C.; Kelley, P. E.; Syka, J. E. P.; Reynolds, W. E; Todd, J. F. J. Int. J. Mass Spectrom. Ion Processes 1984, 60, 85.

7. Cooks, R. G.; Glish, G. L.; McLuckey, S. A. Chem. Eng. News 1991, 69, 26.

8. McLuckey, S. A.; Van Berkel, G. J.; Goeringer, D. E.; Glish, G. L. Anal. Chem. 1994, 66, 689A.

9. March, R. E.; Hughes, R. J. Quadrupole Storage Mass Spectrometry; Wiley, New York, 1989.

10. Bingham, R. C.; Dewar, M. J. S.; Lo, D. H. J. Am. Chem. Soc. 1975, 97, 1285.

11. Lias, S. G.; Bartmess, J. E.; Liebman, J. F.; Holmes, J. L.; Levin, R. D.; Mallard, W. G. J. Phys. Chem. Ref. Data 1988, 1/(1).

12. Ausloos, P.; Lias, S. G.; Buckley, T. J.; Rogers, E. E. Int. J. Mass Spectrom. Ion Processes 1989, 92, 65.

13. deFrees, D. J.; McIver, R. T.; Hehre, W. J. J. Am. Chem. Soc. 1977, 99, 3853.

14. Lau, Y. K.; Kebarle, P. J. Am. Chem. Soc. 1976, 98, 7452.

15. Catalan, J.; Yanez, M. J. Chem. Soc., Perkin Trans. 2 1979, 741.

16. Wood, K. V.; Burinsky, D. J.; Cameron, D.; Cooks, R. G. J. Org. Chem. 1983, 48, 5236.

17. Martinsen, D. P.; Buttrill, S. E., Jr. Org. Mass Spectrom. 1976, 11,762 .
18. Williams, D. H.; Hvistendahl, G. J. Am. Chem. Soc. 1994, 96, 6753.

19. Pollack, S. K.; Devlin, J. L., III; Summerhays, K. D.; Taft, R. W.; Hehre, W. J. J. Am. Chem. Soc. 1977, 99, 4583.

20. Summerhays, K. D.; Pollacks, S. K.; Taft, R. W.; Here, W. J. J. Am. Chem. Soc. 1977, 99, 4585.

21. Catalan, J.; Yanez, M. Chem. Phys. Lett. 1979, 60, 499.

22. Smith, R. L.; Chyall, L. J.; Beaseley, B. J.; Kenttamaa, II. I. J. Am. Chem. Soc. 1995, 117, 7991.

23. Nold, M. J.; Wesdemiotis, C. Proceedings of the 43rd ASMS Conference on Mass Spectrometry and Allied Topics; Atlanta, Georgia, May 21, 1995.

24. Rylander, P. N.; Meyerson, S.; Eliel, E. L.; McCollum, J. D. I. Am. Chem. Soc. 1963, 85, 2723.

25. Lifshitz, C.; Gotchingulan, P.; Roiler, R. Chem. Phys. Lett. $1983,95,106$

26. Burgers, P. C.; Holmes, J. L.; Mommers, A. A.; Terlouw, J. K. Chem. Phys. Lett. 1983, 102, 1.

27. Dookeran, N. N.; Harrison, A. G. J. Am. Soc, Mass Spectrom. $1995,6,19$.

28. Meot-Ner (Mautner), M. J. Am. Chem. Soc. 1979, 101, 2389-2395.

29. Meisels, G. G.; Verboom, G. M. L.; Weiss, M. J.; Hsieh, I. C. J. Am. Chem. Soc. 1979, 101, 7189.

30. Chesnavich, W. J.; Bass, L.; Su, T.; Bowers, M. T. J. Chem. Phys. 1981, 74, 2228.

31. Glish, G. L.; Goeringer, D. E.; Asano, K. G.; McLuckey, S. A. Int. J. Mass Spectrom. Ion Processes 1989, 94, 15-24. 